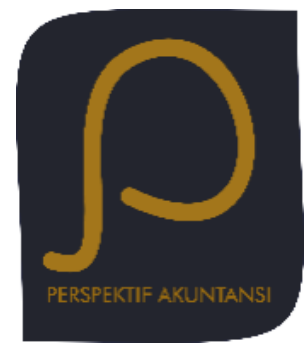

Perspektif Akuntansi

Volume 3 Nomor 2 (Juni 2020), hal. 85-107

ISSN: 2623-0194(Print), 2623-0186(Online)

Copyright(C) The Authors(s). All Rights Reserved

Fakultas Ekonomika dan Bisnis,

Universitas Kristen Satya Wacana

DOI: https://doi.org/10.24246/persi.v1i2.p85-107

http://ejournal.uksw.edu/persi

\title{
Pengaruh Kepemilikan Keluarga dan Likuiditas terhadap Agresivitas Pajak dengan Pemoderasi Corporate Governance
}

\author{
Anggi Aditya Fahmi ${ }^{1}$ \\ Fakultas Ekonomika dan Bisnis, Universitas Kristen Satya Wacana \\ Priyo Hari Adi \\ Fakultas Ekonomika dan Bisnis, Universitas Kristen Satya Wacana
}

Received Abstract. The purpose of this study is to find out how the influence of 11/04/2019 companies with family ownership and liquidity on tax aggressiveness

which is moderated by corporate governance in manufacturing Accepted companies listed on the Indonesia Stock Exchange from 2013 to 2016. 24/02/2020 Corporate governance is proxied using independent commissioners and audit committees. The sample used in this study amounted to 212 selected using the purposive sampling method. The data analysis technique used are moderated regression analysis (MRA). The results showed that family ownership did not affect the tax aggressiveness, this means that companies with family ownership do not determine the company's actions in conducting tax aggressiveness. Liquidity has a significant positive effect on tax aggressiveness. The moderating variable of independent commissioners can moderate the influence of family ownership and liquidity on tax aggressiveness, while the moderating variable of the audit committee can moderate liquidity but cannot moderate family ownership against tax aggressiveness.

Keywords: Tax Aggressiveness, Family Ownership, Liquidity, Corporate governance 


\begin{abstract}
Abstrak. Tujuan penelitian ini adalah untuk mengetahui bagaimana pengaruh perusahaan dengan kepemilikan keluarga dan likuiditas terhadap agresivitas pajak yang dimoderasi oleh corporate governance pada perusahaan manufaktur yang terdaftar di Bursa Efek Indonesia pada tahun 2013 sampai 2016. Corporate governance diproksikan menggunakan komisaris independen dan komite audit. Sampel yang digunakan dalam penelitian ini berjumlah 212 yang dipilih dengan menggunakan metode purposive sampling. Teknik analisis data yang digunakan adalah moderated regression analysis (MRA). Hasil penelitian menunjukkan bahwa kepemilikan keluarga tidak berpengaruh terhadap agresivitas pajak, hal ini berarti perusahaan dengan kepemilikan keluarga tidak menentukan tindakan perusahaan dalam melakukan agresivitas pajak. Likuiditas berpengaruh positif signifikan terhadap agresivitas pajak. Variabel moderasi komisaris independen dapat memoderasi pengaruh kepemilikan keluarga dan likuiditas terhadap agresivitas pajak, sedangkan variabel moderasi komite audit dapat memoderasi likuiditas tetapi tidak dapat memoderasi kepemilikan keluarga terhadap agresivitas pajak.
\end{abstract}

Kata kunci: Agresivitas Pajak, Kepemilikan Keluarga, Likuiditas, Corporate governance

\title{
Pendahuluan
}

Pajak merupakan sumber pendapatan terbesar bagi Indonesia untuk menyeimbangkan pendapatan dan pengeluaran negara. Peranan penting pajak yaitu sebagai alat bagi pemerintah untuk melaksanakan pembangunan nasional untuk pemerataan dan kesejahteraan masyarakat (Luke \& Zulaikha, 2016). Bagi wajib pajak, pembayaran pajak merupakan bentuk pengabdian untuk berkontribusi dalam pembangunan nasional (Fahriani, 2016). Namun pelaksanaan dalam pemungutan pajak oleh pemerintah dirasa belum optimal. Oleh sebab itu, perihal mengenai pemungutan pajak merupakan sesuatu yang penting dan harus menjadi perhatian pemerintah dengan pengelolaan yang baik (Fahriani, 2016).

Pemerintah dalam melaksanakan pemungutan pajak kepada perusahaan tidak serta merta mendapat tanggapan yang baik. Suatu perusahaan didirikan mempunyai tujuan yaitu memaksimalkan keuntungan dan memenuhi kepentingan stakeholder. Perusahaan merupakan salah satu wajib pajak yang berkontribusi tinggi dalam penerimaan negara akan berusaha meminimalkan segala bentuk pengeluaran operasional maupun non operasional termasuk pembayaran pajak agar memperoleh keuntungan atau laba yang optimal untuk memaksimalkan kepentingan stakeholder agar kelangsungan kehidupan perusahaan kedepannya dapat terjaga. Sedangkan bagi pemerintah, menginginkan penerimaan pajak setinggi mungkin agar pembiayaan pemerintahan dapat terpenuhi (Fahriani, 2016). Kepentingan pemerintah dan 
perusahaan yang berbeda tersebut membuat perusahaan melakukan berbagai tindakan penghindaran pajak baik secara legal (tax avoidance) maupun illegal (tax evasion) agar pajak yang terhutang bisa berkurang (Darmawan \& Sukartha, 2014).

Pengertian tindakan pajak agresif merupakan suatu bentuk pengelolaan manajemen menggunakan perencanaan pajak dengan tujuan menurunkan laba kena pajak baik secara legal maupun illegal (Frank, Lynch, \& Rego, 2009). Semakin perusahaan melakukan penghindaran terhadap pajak dengan cara mencari celah-celah dalam undang-undang perpajakan, perilaku tersebut yang dinilai tindakan yang semakin agresif. Namun perusahaan tidak begitu saja bertindak agresif terhadap pajak, mereka akan mempertimbangkan dampak bagi perusahaan untuk kedepannya. Dampak melakukan tindakan pajak agresif bagi perusahaan dapat dikelompokkan menjadi marginal benefit dan marginal cost (Desai \& Dharmapala, 2004).

Kepemilikan keluarga merupakan salah satu indikator yang mempunyai kemungkinan berpengaruh terhadap tindakan pajak agresif (Chen , Chen , Cheng, \& Shevlin, 2010). Perusahaan dengan kepemilikan keluarga menghadirkan persoalan yang unik mengingat konflik keagenan yang akan muncul. Kepemilikan keluarga akan mengakibatkan munculnya konflik keagenan yang lebih besar antara pemilik minoritas dengan mayoritas dan akan memunculkan konflik keagenan yang lebih kecil antara hubungan manajer dengan pemilik. Konflik keagenan seperti ini dapat berpengaruh terhadap tingkat agresivitas pajak (Chen, Chen, Cheng, \& Shevlin, 2010). Tingkat masalah keagenan dalam perusahaan didasari dengan seberapa besar biaya dan manfaat yang didapatkan setelah melakukan tindakan pajak agresif. Khususnya terhadap pemilik perusahaan dengan kepemilikan keluarga atau dampak yang didapatkan manajer dengan perusahaan non-keluarga (Sari \& Martani, 2010).

Indikator lainnya yang mempunyai kemungkinan berpengaruh dengan tindakan pajak agresif yaitu likuiditas (Siahaan, 2005). Pajak perusahaan adalah salah satu bagian dari hutang lancar. Kemampuan perusahaan dalam melaksanakan hutang lancarnya dapat diukur menggunakan rasio likuiditas. Apabila rasio likuiditas perusahaan tinggi, maka perusahaan dalam keadaan arus kas yang lancar. Maka hutang lancar perusahaan akan mampu dipenuhi apabila dalam kondisi yang tinggi pada rasio likuiditasnya (Suyanto \& Supramono, 2012). Sebaliknya, apabila dalam kondisi rasio likuiditas yang rendah maka perusahaan akan tidak taat dalam pembayaran pajak. Perusahaan tidak akan membayar pajak yang terutang dan lebih memilih untuk mempertahankan arus kas (Siahaan, 2005). 
Kepemilikan keluarga dan likuiditas perusahaan dengan tindakan pajak agresif mempunyai kemungkinan berhubungan terhadap masalah corporate governance. Corporate governance merupakan salah satu alat yang digunakan untuk memerangi tindakan pajak agresif, namun meskipun sudah banyak perusahaan yang menerapkannya, tidak menutup kemungkinan perusahaan masih melakukan tindakan pajak agresif (Desai \& Dharmapala, 2004). Dengan perusahaan menerapkan corporate governance, diharapkan masalah agensi dapat teratasi dan kinerja perusahaan dapat meningkat. Corporate governance dalam penelitian ini diproksikan menjadi komisaris independen dan komite audit. Pernyataan tersebut diperkuat dengan penelitian yang dilakukan oleh Fahriani (2016) dan penelitian Hidayanti dan Laksito (2013) yang menguji pengaruh corporate governance terhadap agresivitas pajak. Dari hasil penelitian tersebut diperoleh bukti bahwa terdapat pengaruh corporate governance terhadap agresivitas pajak.

Penelitian mengenai pengaruh kepemilikan keluarga terhadap agresivitas pajak semakin menarik untuk dilakukan. Kepemilikan keluarga merupakan variabel yang unik untuk diteliti karena pengklasifikasian perusahaan dengan kepemilikan keluarga relatif sulit dibandingkan dengan kepemilikan lainnya. Kepemilikan keluarga juga memiliki masalah agensi yang relatif besar antara kepemilikan saham mayoritas dengan minoritas, hal ini dapat berpengaruh terhadap tindakan agresif terhadap pajak. Selain itu, penelitian dengan topik ini sudah beberapa kali dilakukan dan memberikan hasil yang tidak konsisten. Penelitian yang dilakukan oleh Chen, Chen , Cheng dan Shevlin (2010), Hidayanti dan Laksito (2013), Utami dan Setyawan, (2015), Ardy dan Kristanto (2015) menunjukkan tidak ada pengaruh antara kepemilikan keluarga dengan agresivitas pajak. Temuan ini berbeda dengan Sari dan Martani (2010) serta Praptidewi dan Sukartha (2016) yang menunjukkan fakta empirik adanya pengaruh antara kepemilikan keluarga dengan agresivitas pajak.

Berbeda dengan penelitian sebelumnya yang dilakukan oleh Sirait dan Martani (2014) penelitian ini menambahkan variabel likuiditas untuk melihat pengaruh terhadap agresivitas pajak pada faktor keuangan seperti penelitian yang dilakukan oleh Adisamartha dan Noviari (2015), menambahkan corporate governance sebagai variabel moderasi dalam fungsi pengawasan seperti penelitian yang dilakukan oleh Utami dan Setyawan (2015). Penerapan konsep corporate governance yang optimal dianggap mampu menjadi variabel pemoderasi dalam penelitian ini. Corporate governance memiliki lima prinsip yaitu diantaranya transparansi, akuntabilitas, independensi, pertanggungjawaban, dan keadilan yang perlu diterapkan bagi perusahaan, terlebih pada prinsip independensi yang harus diterapkan 
dengan optimal untuk menekan tindakan agresif terhadap pajak pada perusahaan keluarga. Menggunakan periode waktu penelitian yang berbeda sesuai saran penelitian sebelumnya. Penelitian ini bertujuan untuk menyelidiki pengaruh kepemilikan keluarga dan likuiditas terhadap agresivitas pajak dengan corporate governance sebagai variabel pemoderasi pada perusahaan manufaktur yang terdaftar pada Bursa Efek Indonesia. Harapan adanya penelitian ini yaitu dapat dimanfaatkan Direktorat Jenderal Pajak untuk mengenali indikator perusahaan melakukan tindakan pajak agresif. Dapat menambah literatur terkait faktor-faktor penghindaran pajak bagi peneliti lain yang akan meneliti pada topik yang sama secara lebih mendalam.

\section{Telaah Pustaka}

\section{Agresivitas Pajak}

Agresivitas pajak dapat didefinisikan sebagai suatu bentuk pengelolaan manajemen dengan tujuan menurunkan laba kena pajak baik secara legal ( $\operatorname{tax}$ avoidance) maupun ilegal (tax evasion) (Frank, Lynch, \& Rego, 2009). Pengertian dari tax avoidance yaitu perilaku penghindaran pajak yang dilakukan perusahaan yang bersifat legal dan aman tanpa menyalahi ketentuan atau peraturan perpajakan yang berlaku. Tax avoidance tersebut menggunakan teknik yaitu memanfaatkan berbagai kelemahan dalam Peraturan Perpajakan dengan tujuan menekan jumlah pengenaan pajak yang seharusnya dibayarkan perusahaan. Perusahaan dengan pendapatan yang besar berkemungkinan memiliki beban pajak yang kecil atau rendah. Beban pajak yang rendah tersebut karena perusahaan dapat memanfaatkan peluang dari adanya insentif pajak atau pengurangan pajak lainnya (Darmadi , 2013). Pengertian dari tax evasion yaitu perilaku penghindaran pajak oleh perusahaan yang bersifat ilegal dan tidak aman, dimana wajib pajak dengan sengaja memperlihatkan keadaan yang tidak semestinya. Tax evasion tersebut menggunakan teknik yang tidak aman bagi perusahaan atau menyalahi koridor Undang-Undang Perpajakan yang merugikan pemerintah (Pohan, 2011).

\section{Keuntungan dan Kerugian Tindakan Pajak Agresif}

Menurut Desai dan Dharmapala (2004) apabila perusahaan melakukan tindakan pajak agresif akan ada berbagai keuntungan (marginal benefit) dan kerugian (marginal cost). Keuntungan atau marginal benefit atas tindakan pajak agresif yang dilakukan perusahaan diantaranya penghematan pajak yang dirasakan perusahaan, yang mengakibatkan pemilik menikmati porsi kas lebih besar. Kedua, manajer memperoleh kompensasi atas kinerjanya 
membuat pajak terutang perusahaan menjadi lebih kecil. Dan yang terakhir, kesempatan pribadi manajer melakukan rent extraction, yaitu segala perilaku atau tindakan manajer yang tidak memaksimalkan kepentingan pemilik, lebih kepada pemenuhan kepentingan pribadi manajer. Perilaku tersebut diantaranya pengambilan sumber daya atau aset perusahaan, melakukan penyusunan laporan yang tidak semestinya, dan melakukan transaksi terhadap pihak istimewa. Sedangkan kerugian atau marginal cost atas tindakan pajak agresif yang dilakukan perusahaan diantaranya perusahaan memperoleh hukuman berupa penalti atau sanksi administrasi dari petugas pajak akibat dilakukan audit dan ditemukan berbagai kecurangan yang dilakukan perusahaan. Kedua, tercederainya nama baik atas perusahaan akibat audit yang dilakukan oleh petugas perpajakan. Dan yang terakhir, harga saham mengalami penurunan diakibatkan adanya pendapat dari pemegang saham bahwa manajemen melakukan tindakan rent extraction untuk keutungan pribadi yang menyebabkan kerugian bagi pemegang saham baik mayoritas maupun minoritas.

\section{Kepemilikan Keluarga}

Definisi perusahaan dengan kepemilikan keluarga yaitu perusahaan yang didirikan atau dijalankan berlandaskan warisan atau keturunan dari pihakpihak yang terlebih dahulu sudah menjalankan perusahaan tersebut atau dari keluarga yang mewariskan perusahaan tersebut kepada generasi selanjutnya dengan cara terang-terangan (Morck \& Yeung, 2004). Menurut Arifin (2003) dalam Hidayanti dan Laksito (2013) definisi kepemilikan keluarga yaitu semua perusahaan dan individu yang tercatat kepemilikannya (wajib dicatat apabila kepemilikan > 5\%), yang bukan merupakan perusahaan milik negara, institusi keuangan, dan publik (individu yang kepemilikan atas perusahaan tidak wajib dicatat).

\section{Likuiditas}

Definisi dari likuiditas yaitu kemampuan suatu perusahaan dalam memenuhi kewajiban jangka pendeknya menggunakan aktiva lancar. Dalam hal ini "jangka pendek" merupakan periode yang berakhir hingga satu tahun (Siahaan, 2005). Jika suatu perusahaan tidak berhasil dalam memenuhi kewajiban jangka pendeknya, maka going concern atau kelangsungan hidup suatu perusahaan dipertanyakan. Perusahaan yang mengalami kesulitan dalam memenuhi kewajiban jangka pendeknya memperlihatkan bahwa entitas tersebut dalam kondisi likuiditas yang rendah. Kesulitan likuiditas tersebut dapat menyebabkan perusahaan tidak patuh terhadap ketentuan perpajakan dan dapat memicu tindakan agresif terhadap pajak perusahaan (Siahaan, 2005). 


\section{Corporate governance}

Menurut Desai dan Dharmapala (2004) definisi dari Good Corporate Governance adalah sistem untuk mengendalikan dan mengatur sebuah perusahaan demi terciptanya nilai tambah bagi semua stockholder. Sedangkan pengertian dari corporate governance menurut Kurniasih dan Sari (2013) yaitu sebagai efektifitas dalam mekanisme yang mempunyai tujuan untuk meminimalkan konflik keagenan dengan melakukan penekanan khusus terhadap mekanisme legal untuk ekspropriasi atas pemegang saham minoritas. Terdapat prinsip-prinsip dasar yang ada didalam corporate governance diantaranya yaitu transparansi, akuntabilitas, pertanggungjawaban, kemandirian, dan kewajaran. Prinsip-prinsip tersebut dapat diterapkan perusahaan demi tercapainya kesinambungan usaha dengan memperhatikan kepentingan dari stakeholders (Fahriani, 2016).

FCGI (2003) dalam Suyanto dan Supramono (2012) mengatakan bahwa Indonesia menerapkan sistem kontinental mempunyai dua tingkatan dalam berjalannya suatu tata kelola perusahaan. Dua tingkatan tersebut yaitu dewan direksi dan dewan komisaris. Dalam anggota dewan komisaris terdapat komisaris independen yang sama sekali tidak mempunyai hubungan khusus yang akan mempengaruhi sikap independennya. Dalam hal pengawasan, komisaris independen dinilai lebih baik karena tidak terpengaruh oleh kepentingan internal perusahaan dan apabila proporsinya semakin banyak maka pengawasan menjadi semakin diperketat. Dalam hal ini, kewajiban dewan komisaris yang lain yaitu membentuk komite audit yang beranggotakan minimal tiga orang (Pohan, 2011). Komite audit bertugas membantu dewan komisaris. Tugas yang harus dilakukan antara lain memberikan kepastian bahwa laporan keuangan telah disajikan dengan wajar, pengendalian internal yang dirancang perusahaan dapat berjalan dengan semestinya, memastikan berlandaskan standar atas pelaksanaan audit eksternal dan audit internal dan manajemen merespon temuan audit dengan melaksanakan tindak lanjut (Fahriani, 2016).

\section{Pengembangan Hipotesis}

Perusahaan dengan kepemilikan keluarga mempunyai konflik agensi lebih kecil yaitu antara pemilik dengan manajer. Tindakan perusahaan melakukan agresivitas pajak didukung dari pemegang saham mayoritas yang bertindak sebagai pendiri (Chen, Chen, Cheng, \& Shevlin, 2010). Struktur kepemilikan keluarga di Asia berbentuk struktur kepemilikan piramida begitu juga dengan Indonesia (Rudsyi \& Martani, 2014). Di Indonesia menunjukkan fenomena bahwa sebagian besar perusahaan kepemilikan keluarga bertindak agresif terhadap pajak (Wirawan \& Sukartha, 2018). Manajemen perusahaan dapat 
dipengaruhi oleh pemegang saham mayoritas yang memungkinkan para manajer bertindak sesuai keinginan pemilik, tidak menutup kemungkinan untuk mengurangi beban pajak dan melakukan tindakan agresif terhadap pajak.

Manfaat dari tindakan agresivitas pajak akan lebih tinggi dirasakan pada perusahaan dengan kepemilikan keluarga karena konflik keagenan yang ada dalam perusahaan lebih kecil dibandingkan perusahaan dengan kepemilikan non keluarga (Chen, Chen , Cheng, \& Shevlin, 2010). Penelitian Sirait dan Martani (2014) pada perusahaan yang ada di Malaysia dan penelitian Chen, Chen, Cheng, dan Shevlin (2010) pada perusahaan yang ada di Amerika Serikat memberikan hasil bahwa kepemilikan keluarga tidak berpengaruh terhadap agresivitas pajak. Berbeda dengan penelitian yang dilakukan oleh Sari dan Martani (2010) serta Praptidewi dan Sukartha (2016) yang memberikan hasil bahwa kepemilikan keluarga berpengaruh signifikan terhadap agresivitas pajak, perbedaan hasil ini terlihat jelas dengan tax ratio negara tersebut berada di atas Indonesia. Selain itu, pemilik mayoritas adalah keluarga tentu memiliki hak suara lebih besar sehingga pemilik dapat menentukan arah kebijakan bagi perusahaan. Berdasarkan uraian diatas tersebut maka dapat dirumuskan hipotesis sebagai berikut:

\section{$\mathrm{H}_{1}$ : Kepemilikan keluarga berpengaruh positif terhadap agresivitas pajak.}

Pajak merupakan salah satu kewajiban jangka pendek perusahaan. Pemenuhan kewajiban jangka pendek perusahaan dapat dilihat menggunakan rasio likuiditas. Perusahaan dengan tingkat likuiditas yang tinggi memberikan arti bahwa perusahaan dalam keadaan arus kas yang lancar (Suyanto \& Supramono, 2012). Begitupun sebaliknya, apabila tingkat likuiditas suatu perusahaan rendah berarti perusahaan akan tidak taat dalam pembayaran pajak.

Penelitian yang telah dilakukan oleh Siahaan (2005) memberikan suatu hasil bahwa perusahaan dalam kondisi kesulitan likuiditas mempunyai kecenderungan bahwa mereka tidak akan patuh terhadap peraturan yang telah ditetapkan dalam perpajakan dan kemungkinan besar akan melakukan tindakan pajak agresif. Tindakan semacam ini dilakukan untuk menekan pengeluaran atas pajak yang dibebankan dan untuk mempertahankan kestabilan pada arus kas. Oleh sebab itu perusahaan dengan rasio likuiditas rendah akan memiliki kecenderungan tinggi dalam agresivitas pajak perusahaan. Berdasarkan uraian hubungan diatas, dapat dirumuskan hipotesis sebagai berikut:

\section{$\mathrm{H}_{2}$ : Likuiditas berpengaruh negatif terhadap agresivitas pajak.}


Perusahaan dengan kepemilikan saham mayoritas dimiliki oleh keluarga akan mempunyai pengaruh besar dalam menentukan kebijakan-kebijakan yang diambil suatu perusahaan. Tidak menutup kemungkinan kebijakan yang dibuat lebih menguntungkan untuk kepentingan pribadi karena konflik keagenan yang relatif lebih kecil antara manajemen dan pemegang saham. Hal ini dikarenakan penghematan pajak yang didapatkan lebih besar dibandingkan sangsi atau denda yang diberikan fiskus atas tindakan pajak agresif. Hal ini diperkuat oleh penelitian dari Sari dan Martani (2010) yang menunjukkan bahwa tindakan pajak agresif lebih besar pada perusahaan keluarga.

Hidayanti dan Laksito (2013) berpendapat bahwa penerapan prinsip-prinsip corporate governance oleh sebuah perusahaan akan mampu membuat pengawasan terhadap internal perusahaan menjadi lebih baik. Dengan perusahaan menerapkan berbagai prinsip corporate governance seperti independensi, transparansi, akuntabilitas, tanggung jawab, dan keadilan maka fungsi tata kelola dan pengawasan perusahaan menjadi lebih terstruktur dan transparan hingga sedikit demi sedikit praktik-praktik kecurangan dapat teratasi. Hal ini diperkuat oleh Fahriani (2016) yang menyatakan bahwa corporate governance berpengaruh terhadap agresivitas pajak. Berdasarkan uraian hubungan diatas, dapat dirumuskan hipotesis sebagai berikut:

\section{$\mathrm{H}_{3 \mathrm{a}}: \quad$ Komisaris independen dapat memoderasi pengaruh kepemilikan keluarga pada agresivitas pajak.}

$\mathrm{H}_{3 \mathrm{~b}}$ : Komite audit dapat memoderasi pengaruh kepemilikan keluarga pada agresivitas pajak.

Corporate governance dapat memoderasi pengaruh Likuiditas pada Agresivitas Pajak

Perilaku manajemen seringkali bersifat opportunistic, mereka memiliki motivasi agar penerimaan laba dapat diperoleh setinggi mungkin agar komisi yang diterima bisa meningkat (Nuryaman, 2009). Cara manajemen memaksimalkan laba bersih yaitu dengan menekan biaya-biaya perusahaan tidak terkecuali pegeluaran terhadap pajak. Pernyataan ini dapat menggerakkan manajer bertindak agresif terhadap pajak. Dengan adanya komite audit yang bertanggung jawab dalam pengawasan berbagai kegiatan perusahaan, dapat mengurangi manajemen untuk melakukan manajemen laba (earnings management).

Dengan adanya komisaris independen pula dapat meningkatkan pengawasan menjadi lebih baik untuk mengarahkan perilaku manajemen sesuai aturan yang berlaku. Berjalannya fungsi corporate governance secara efektif dapat 
menekan terjadinya kecurangan-kecurangan manajemen yang sering terjadi pada perusahaan di Indonesia (Nuryaman, 2009). Lanis dan Richardson (2012) berpendapat bahwa tindakan agresif terhadap pajak dapat berkurang dengan lebih independennya tata kelola sebuah perusahaan. Hal ini diperkuat oleh Yogiswari dan Ramantha, (2017) yang memberikan hasil bahwa corporate governance dapat memoderasi pengaruh likuiditas pada agresivitas pajak. Berdasarkan uraian hubungan diatas, dapat dirumuskan hipotesis sebagai berikut:

$\mathrm{H}_{4 \mathrm{a}}$ : Komisaris Independen dapat memoderasi pengaruh likuiditas pada agresivitas pajak.

$H_{4 b}$ : Komite Audit dapat memoderasi pengaruh likuiditas pada agresivitas pajak.

\section{Model Penelitian}

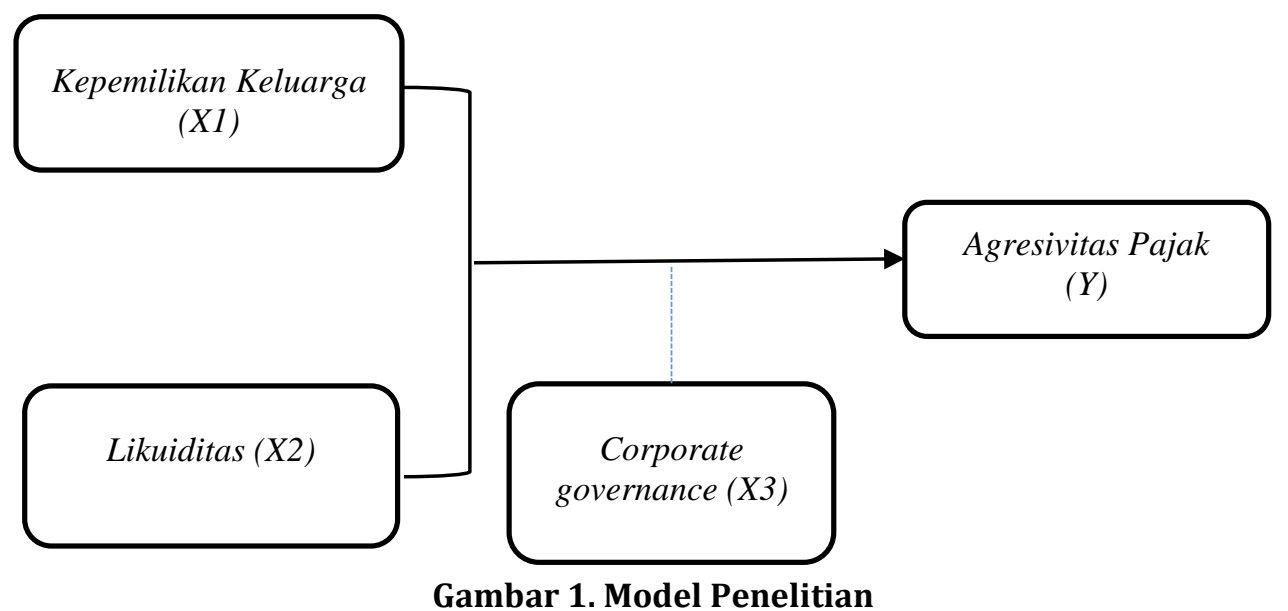

\section{Metoda}

\section{Jenis Penelitian}

Penelitian ini menggunakan metode kuantitatif untuk meneliti pengaruh pengaruh kepemilikan keluarga dan likuiditas terhadap agresivitas pajak dengan corporate governance sebagai variabel pemoderasi pada perusahaan manufaktur yang terdaftar di Bursa Efek Indonesia (BEI) pada tahun 20132016.

\section{Data dan Sumber Data}

Data yang digunakan dalam penelitian ini adalah data sekunder dalam bentuk time series dan cross section (data panel). Data yang digunakan berupa beban pajak, laba sebelum pajak, informasi kepemilikan saham pengendali, aset lancar, kewajiban lancar, proporsi komisaris independen, dan proporsi komite audit pada perusahaan-perusahaan manufaktur yang terdaftar di 
Bursa Efek Indonesia (BEI) pada tahun 2013-2016 diperoleh dari sumber www.idx.co.id dan Indonesia Capital Market Directory (ICMD).

\section{Populasi dan Sampel}

Populasi pada penelitian ini mencakup seluruh perusahaan manufaktur di Bursa Efek Indonesia (BEI) tahun 2013 sampai dengan 2016. Selanjutnya akan dilakukan pengambilan sampel dengan menggunakan teknik purposive sampling yaitu menentukan sampel berdasar kriteria. Kriteria yang digunakan adalah:

1. Perusahaan manufaktur yang terdaftar pada BEI pada tahun 2013-2016.

2. Perusahaan manufaktur yang mempublikasikan laporan perusahaan secara konsisten pada tahun 2013-2016.

3. Perusahaan manufaktur yang mengalami laba positif berturut-turut 20132016.

4. Perusahaan manufaktur yang mempublikasikan laporan keuangan dengan menggunakan mata uang rupiah 2013-2016.

\section{Pengukuran Variabel}

Dalam penelitian ini variabel bebas menggunakan likuiditas dan kepemilikan keluarga sementara variabel terikat yang digunakan adalah agresivitas pajak dan corporate governance sebagai variabel pemoderasi. Adapun pengukuran untuk masing-masing variabel dilakukan dengan cara sebagai berikut:

Tabel 1 Pengukuran Variabel

\begin{tabular}{ccl}
\hline $\begin{array}{c}\text { Jenis } \\
\text { Variabel }\end{array}$ & Variabel & \multicolumn{1}{c}{ Ukuran } \\
\hline Variabel & Agresivitas Pajak & Menggunakan pengukuran effective tax rate \\
Dependen & & (ETR) yaitu beban pajak penghasilan dibagi \\
& & dengan laba sebelum pajak (Utami \& Setyawan, \\
& & $2015)$. \\
\hline
\end{tabular}




\begin{tabular}{|c|c|c|}
\hline Variabel & Kepemilikan & Menggunakan dummy variabel, \\
\hline Independen & Keluarga & $\begin{array}{l}\text { ketentuan akan bernilai } 1 \text { apabila proporsi } \\
\text { kepemilikan keluarga suatu perusahaan }>50 \% \text {, } \\
\text { dan akan bernilai } 0 \text { apabila }<50 \% \text {. Penelitian } \\
\text { ini mengelompokkan perusahaan dengan } \\
\text { kepemilikan keluarga berdasarkan kualifikasi } \\
\text { perusahaan yang dikendalikan dan dipimpin } \\
\text { oleh pihak-pihak dimana anggota keluarga atau } \\
\text { pendiri mereka memiliki peran penting sebagai } \\
\text { eksekutif kunci, pemilik saham atau direksi } \\
\text { dengan persentase } \geq 5 \% \text { yang bukan } \\
\text { merupakan perusahaan milik negara, institusi } \\
\text { keuangan, dan publik (Chen, Chen, Cheng, \& } \\
\text { Shevlin, 2010). }\end{array}$ \\
\hline $\begin{array}{c}\text { Variabel } \\
\text { Independen }\end{array}$ & Likuiditas & $\begin{array}{l}\text { Menggunakan rasio lancar dalam penelitian } \\
\text { kali ini yaitu menggunakan rumus aset lancar } \\
\text { dibagi dengan kewajiban lancar perusahaan } \\
\text { (Suyanto \& Supramono, 2012). }\end{array}$ \\
\hline $\begin{array}{l}\text { Variabel } \\
\text { Moderasi }\end{array}$ & Corporate governance & $\begin{array}{l}\text { Menggunakan dua proksi dalam penelitian kali } \\
\text { ini yaitu komposisi komite audit dan komisaris } \\
\text { independen. Untuk mengukur komite audit } \\
\text { yaitu dengan jumlah keseluruhan anggota } \\
\text { komite audit tersebut dalam suatu perusahaan } \\
\text { sesuai sampel tahun yang diamati (Hanum \& }\end{array}$ \\
\hline & & $\begin{array}{l}\text { Zulaikha, 2013). Sedangkan komisaris } \\
\text { independen diukur menggunakan persentase } \\
\text { komisaris independen terhadap total dewan } \\
\text { komisaris sesuai sampel tahun yang diamati } \\
\text { (Andriyani, 2008). }\end{array}$ \\
\hline
\end{tabular}

\section{Teknik Analisis Data}

Analisis dan interpretasi sangat diperlukan untuk membantu menjawab setiap pertanyaan yang ada. Analisis linier berganda digunakan dalam penelitian ini yang dioperasikan melalui program SPSS. Namun, sebelum melakukan analisis tersebut perlu dilakukannya uji asumsi klasik terlebih dahulu.

1. Uji Asumsi Klasik

Sebelum dilakukannya pengujian hipotesis, terlebih dahulu akan dilakukan pengujian asumsi klasik mencakup (uji normalitas, uji multikolinieritas, uji heteroskedastisitas, dan uji autokorelasi) agar dapat memberikan kepastian bahwa persamaan regresi yang didapatkan memiliki ketepatan dan konsisten.

2. Moderated Regression Analysis (MRA)

Liana, (2009) mengungkapkan bahwa Moderated Regression Analysis (MRA) atau uji interaksi merupakan aplikasi khusus regresi berganda 
linear dimana dalam persamaan regresinya mengandung unsur interaksi (perkalian dua atau lebih variabel independen).

Model persamaan regresi dalam penelitian ini sebagai berikut:

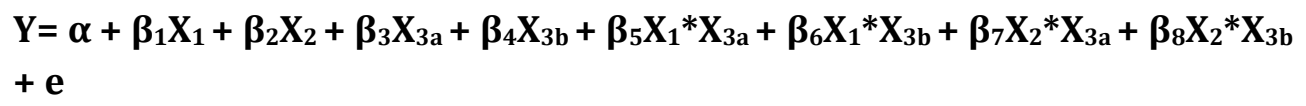

\section{Hasil dan Pembahasan}

\section{Hasil}

\section{Objek Penelitian}

Data perusahaan-perusahaan manufaktur yang terdaftar di Bursa Efek Indonesia selama periode 2013-2016 digunakan dalam penelitian ini yang diperoleh dari situs resmi Bursa Efek Indonesia dan Indonesia Capital Market Directory (ICMD). Metode purposive sampling digunakan untuk menentukan sampel penelitian ini dan diperoleh sampel perusahaan sebanyak 212 perusahaan, proses pemilihan sampel sebagai berikut:

Tabel 2 Proses Pemilihan Sampel Penelitian

\begin{tabular}{ccc}
\hline No. & Kriteria Sampel & Jumlah \\
\hline 1. & Perusahaan Manufaktur yang terdaftar di BEI pada tahun 2013- & 144 \\
2016 & \\
2. & $\begin{array}{c}\text { Perusahaan manufaktur yang tidak mempublikasikan laporan } \\
\text { perusahaan secara konsisten pada tahun 2013-2016 }\end{array}$ & $(24)$ \\
3. & Perusahaan manufaktur yang tidak mengalami laba positif & $(57)$ \\
\hline
\end{tabular}




\begin{tabular}{|c|c|c|c|c|c|}
\hline $\begin{array}{r}\text { Perusahaan } \\
\text { tid }\end{array}$ & \multicolumn{4}{|c|}{$\begin{array}{c}\text { Perusahaan manufaktur yang mempublikasikan laporan keuangan } \\
\text { tidak menggunakan mata uang rupiah 2013-2016 }\end{array}$} & $(10)$ \\
\hline & \multicolumn{4}{|c|}{$\begin{array}{l}\text { Jumlah sampel penelitian } \\
\text { Jumlah tahun penelitian }\end{array}$} & $\begin{array}{c}53 \\
4 \\
212 \\
\end{array}$ \\
\hline \multicolumn{6}{|c|}{ Sumber: Data diolah, 2019} \\
\hline \multicolumn{6}{|c|}{ Statistik Deskriptif } \\
\hline \multicolumn{6}{|c|}{$\begin{array}{l}\text { Setiap kondisi variabel-variabel dalam penelitian ini, digambarkan atau } \\
\text { dideskriptifkan melalui statistik deskriptif yang dapat dilihat dari nila } \\
\text { minimum, maksimum, mean, dan standar deviasi dalam tabel berikut ini: }\end{array}$} \\
\hline \multicolumn{6}{|c|}{ Tabel 3 Statistik Deskriptif } \\
\hline Variabel & $\mathrm{N}$ & Minimum & Maksimum & Rerata & $\begin{array}{l}\text { Deviasi } \\
\text { standar }\end{array}$ \\
\hline Agresifitas Pajak & 212 & 0,01 & 0,94 & 0,2834 & 0,1513 \\
\hline $\begin{array}{l}\text { Kepemilikan } \\
\text { Keluarga }\end{array}$ & 212 & 0,00 & 1,00 & 0,3821 & 0,4870 \\
\hline Likuiditas & 212 & 0,40 & 15,17 & 2,9713 & 2,6338 \\
\hline $\begin{array}{l}\text { Komisaris } \\
\text { Independen }\end{array}$ & 212 & 0,00 & 0,75 & 0,3980 & 0,1070 \\
\hline Komite Audit & 212 & 0,00 & 5,00 & 3,1274 & 0,4544 \\
\hline
\end{tabular}

Sumber: Data diolah, 2019

Berdasarkan tabel 3, diketahui bahwa jumlah data yang digunakan dalam penelitian ini adalah 212 data yang diambil dari laporan tahunan perusahaan manufaktur yang terdaftar di Bursa Efek Indonesia (BEI) pada tahun 20132016. Variabel agresivitas pajak (ETR) memiliki nilai minimum 0,01 yaitu pada kode perusahaan EKAD pada tahun 2013 dan nilai maksimum sebesar 0,94 yaitu pada kode perusahaan UNIT pada tahun 2014. Variabel agresivitas pajak memiliki nilai mean 0,2834 lebih besar dari standar deviasinya yaitu 0,1513 , hal ini menunjukkan bahwa nilai mean dapat merepresentasikan keseluruhan data penelitian.

Variabel kepemilikan keluarga memiliki nilai minimum 0,00 dan nilai maksimum sebesar 1,00. Variabel kepemilikan keluarga memiliki nilai mean 0,3821 lebih kecil dari standar deviasinya yaitu 0,4870 , hal ini menunjukan bahwa nilai mean tidak dapat merepresentasikan keseluruhan data penelitian. Variabel likuiditas memiliki nilai minimum 0,40 yaitu pada kode perusahaan UNIT pada tahun 2013 dan nilai maksimum sebesar 15,17 yaitu pada kode perusahaan DPNS pada tahun 2016. Variabel likuiditas memiliki nilai mean 
2,9713 lebih besar dari standar deviasinya yaitu 2,6338, hal ini menunjukan bahwa nilai mean dapat merepresentasikan keseluruhan data penelitian.

Variabel komisaris independen memiliki nilai minimum 0,00 yaitu pada kode perusahaan IMPC pada tahun 2013 dan nilai maksimum sebesar 0,75 yaitu pada kode perusahaan TSPC pada tahun 2014. Variabel komisaris independen memiliki nilai mean 0,3980 lebih besar dari standar deviasinya yaitu 0,1070, hal ini menunjukan bahwa nilai mean dapat merepresentasikan keseluruhan data penelitian. Variabel komite audit memiliki nilai minimum 0,00 yaitu pada kode perusahaan IMPC pada tahun 2013 dan nilai maksimum sebesar 5,00 yaitu kode pada perusahaan CPIN pada tahun 2013-2016. Variabel komite audit memiliki nilai mean 3,1274 lebih besar dari standar deviasinya yaitu 0,4544, hal ini menunjukan bahwa nilai mean dapat merepresentasikan keseluruhan data penelitian.

\section{Uji Asumsi Klasik}

Penelitian ini menggunakan probability plot untuk melihat normalitas data. Jika persebaran titik data berada di sekitar sumbu diagonal dan mengikuti garis diagonal, maka model regresi penelitian ini memenuhi asumsi normalitas (Ghozali, 2013). Model regresi persamaan ini menunjukan bahwa persebaran titik data penelitian ini berada di sekitar garis diagonal dan mengikuti arah garis diagonal, sehingga model regresi dalam penelitian ini berdistribusi normal dan memenuhi asumsi normalitas. (lihat lampiran)

Dalam penelitian ini, untuk Uji Multikolinieritas yaitu dengan melihat nilai tolerance dan Varian Inflation Factor (VIF). Jika nilai tolerance $>0,10$ dan nilai VIF $<10,00$ maka artinya tidak terjadi multikolinieritas dalam model regresi (Ghozali, 2013). Pada penelitian ini menunjukkan bahwa nilai VIF dari setiap variabel bebas nilainya kurang dari 10,00 yaitu kepemilikan keluarga $(1,027)$, likuiditas $(1,025)$, komisaris independen $(1,023)$, komite audit $(1,025)$ dan nilai tolerance berada diatas 0,10 yakni kepemilikan keluarga $(0,974)$, likuiditas $(0,976)$, komisaris independen $(0,977)$, komite audit $(0,975)$. Dapat disimpulkan bahwa dalam model regresi ini lolos uji multikolinearitas. (lihat lampiran)

Pengujian heterokedastisitas dalam penelitian ini menggunakan analisis grafik scatterplot dari model regresi dalam penelitian ini. Jika persebaran titik data dalam grafik scatterplot berada diatas dan dibawah angka nol, tidak berkumpul diatas atau dibawah saja, dan tidak membentuk pola yang jelas maka tidak terjadi heterokedastisitas (Ghozali, 2013). Pada grafik scatterplot model regresi persamaan ini menunjukan bahwa persebaran titik data berada diatas dan dibawah angka nol, tidak hanya berkumpul diatas atau dibawah, 
dan tidak membentuk pola yang jelas, sehingga model regresi penelitian ini lolos uji heterokedastisitas. (lihat lampiran)

Penelitian ini menggunakan pengujian Run Test untuk mengetahui apakah terdapat autokorelasi dalam data penlitian ini. Jika nilai Asymp. Sig. (2-Tailed) lebih besar > dari 0,05 maka tidak terdapat gejala autokorelasi (Ghozali, 2013). Pada tabel run test Uji Autokorelasi model regresi penelitian ini menunjukkan bahwa nilai Asymp. Sig. (2-Tailed) lebih besar $>$ dari 0,05 yaitu sebesar 0,629. Sehingga model regresi pada penelitian ini lolos uji autokorelasi. (lihat lampiran)

\section{Pengujian Hipotesis}

Pengujian analisis regresi dilakukan dalam rangka menguji hipotesis yang dikembangkan dalam penelitian ini. Pengolahan data dilakukan dengan menggunakan bantuan program SPSS. Hasil analisis regresi pada penelitian ini yaitu sebagai berikut:

Tabel 4 Moderated Regression Analysis (MRA)

\begin{tabular}{|c|c|c|c|c|c|}
\hline \multirow{2}{*}{ Model } & \multicolumn{2}{|c|}{$\begin{array}{l}\text { Unstandardized } \\
\text { Coefficients }\end{array}$} & \multirow{2}{*}{$\mathrm{t}$} & \multirow{2}{*}{ Sig. } & \multirow{2}{*}{ Ket } \\
\hline & B & $\begin{array}{c}\text { Std. } \\
\text { Error }\end{array}$ & & & \\
\hline (Constant) & 0,355 & 0,120 & 2,972 & 0,003 & \\
\hline $\begin{array}{l}\text { Kepemilikan } \\
\text { Keluarga (X1) }\end{array}$ & $-0,066$ & 0,165 & $-0,399$ & 0,690 & H1 Ditolak \\
\hline Likuiditas (X2) & 0,034 & 0,015 & 2,214 & 0,028 & H2 Ditolak \\
\hline $\begin{array}{c}\text { Komisaris } \\
\text { Independen (X3a) }\end{array}$ & 0,685 & 0,145 & 4,726 & 0,000 & - \\
\hline $\begin{array}{l}\text { Komite Audit } \\
\text { (X3b) }\end{array}$ & $-0,062$ & 0,034 & $-1,844$ & 0,067 & - \\
\hline X1*X3a & $-0,531$ & 0,192 & $-2,763$ & 0,006 & H3a Diterima \\
\hline $\mathrm{X} 1 * \mathrm{X} 3 \mathrm{~b}$ & 0,081 & 0,047 & 1,744 & 0,083 & H3b Ditolak \\
\hline $\mathrm{X} 2 * X 3 \mathrm{a}$ & $-0,082$ & 0,034 & $-2,413$ & 0,017 & H4a Diterima \\
\hline $\mathrm{X} 2 * \mathrm{X} 3 \mathrm{~b}$ & $-0,074$ & 0,031 & $-2,366$ & 0,019 & H4b Diterima \\
\hline R square & 0,247 & & & & \\
\hline F hitung & 8,268 & & & & \\
\hline Sig. F & 0,000 & & & & \\
\hline
\end{tabular}

Sumber: Data diolah, 2019

Uji koefisien determinasi dapat menunjukan seberapa jauh variance dari variabel dependen dapat diterangkan oleh variabel independen dengan nilai $\mathrm{R}^{2}$ antara nol dan satu. Berdasarkan hasil uji diatas, $\mathrm{R}$ square bernilai 0,247 yang berarti $24,7 \%$ variasi variabel terikat atau agresivitas pajak dapat diterangkan oleh variabel-variabel bebas dalam penelitian. Sedangkan 75,3\% 
atau nilai sisanya diterangkan oleh faktor lain diluar model regresi penelitian ini.

Uji F dapat menunjukkan bagaimana pengaruh secara simultan antara variabel-variabel independen dalam model regresi pada variabel dependennya. Dari tabel 4 diatas, nilai $\mathrm{F}$ hitung didapat sebesar 8,268 dan nilai signifikansi 0,000. Jadi, dalam model regresi ini variabel independennya terbukti secara simultan memiliki pengaruh yang signifikan terhadap agresivitas pajak karena nilai signifikansi < nilai alpha 0,05.

Uji t dapat menunjukkan bagaimana pengaruh secara parsial antara variabelvariabel independen dalam model regresi pada variabel dependennya. Dari tabel 4 diatas, nilai t hitung untuk variabel kepemilikan keluarga didapat sebesar $-0,399$, nilai koefisien regresi sebesar $-0,066$, dan nilai signifikansi $0,690>$ dari nilai alpha 0,05 . Hasil pengujian ini menunjukkan bahwa kepemilikan keluarga tidak berpengaruh terhadap agresivitas pajak. Kemudian nilai t hitung untuk variabel likuiditas didapat sebesar 2,214, nilai koefisien regresi sebesar 0,034, dan nilai signifikansi 0,028< dari nilai alpha 0,05 . Hasil pengujian ini menunjukkan bahwa likuiditas berpengaruh positif signifikan terhadap agresivitas pajak.

Kemudian untuk variabel moderasi, nilai t hitung untuk variabel interaksi kepemilikan keluarga dengan komisaris independen (X1*X3a) sebesar -2,763, nilai koefisien regresi sebesar $-0,531$, dan nilai signifikansi $0,006<$ dari nilai alpha 0,05. Hasil pengujian ini menunjukkan bahwa komisaris independen dapat memoderasi (memperlemah) pengaruh kepemilikan keluarga terhadap agresivitas pajak. Selanjutnya nilai $t$ hitung untuk variabel interaksi kepemilikan keluarga dengan komite audit (X1*X3b) didapat sebesar 1,744, nilai koefisien regresi sebesar 0,081 dan nilai signifikansi 0,083 > dari nilai alpha 0,05. Dalam hal ini berarti menunjukkan bahwa komite audit tidak dapat memoderasi pengaruh kepemilikan keluarga terhadap agresivitas pajak. Hasil uji selanjutnya untuk variabel interaksi likuiditas dengan komisaris independen $(\mathrm{X} 2 * \mathrm{X} 3 \mathrm{a})$ menunjukkan nilai $\mathrm{t}$ hitung sebesar $-2,413$, nilai koefisien regresi sebesar $-0,082$ dan nilai signifikansi $0,017<$ dari nilai alpha 0,05 . Hasil pengujian ini menunjukkan bahwa komisaris independen dapat memoderasi (memperlemah) pengaruh likuiditas terhadap agresivitas pajak. Hasil uji yang terakhir yaitu variabel interaksi likuiditas dengan komite audit (X2*X3b) menunjukkan nilai t hitung sebesar $-2,366$, nilai koefisien regresi sebesar -0,074 dan nilai signifikansi $0,019>$ dari nilai alpha 0,05. Hasil pengujian ini menunjukkan bahwa komite audit dapat memoderasi (memperlemah) pengaruh likuiditas terhadap agresivitas pajak. 


\section{Pembahasan}

Berdasarkan hasil pengujian statistik diatas didapat bahwa kepemilikan keluarga tidak berpengaruh terhadap agresivitas pajak, maka $\mathrm{H} 1$ yang menyatakan bahwa kepemilikan keluarga berpengaruh positif terhadap agresivitas pajak ditolak. Hasil penelitian ini sejalan dengan penelitian sebelumnya yang dilakukan oleh Chen, Chen , Cheng, dan Shevlin(2010) serta Ardy dan Kristanto (2015). Hasil ini menunjukkan bahwa besarnya kepemilikan keluarga tidak menentukan agresivitas pajak yang dilakukan perusahaan. Perusahaan dengan kepemilikan keluarga mempunyai kepemilikan perusahaan yang lebih besar, rentang waktu untuk investasi lebih lama, serta mempunyai rasa kepedulian yang lebih tinggi mengenai nama baik perusahaan.

Oleh sebab itu, perusahaan dengan kepemilikan keluarga akan melindungi kepentingan perusahaan dalam jangka panjang yang berkaitan dengan munculnya risiko kerugian yang diakibatkan perusahaan melakukan tindakan agresif terhadap pajak. Perusahaan keluarga menganggap bahwa akan lebih besar dalam pengeluaran biaya daripada manfaat yang diterima setelah melakukan tindakan pajak agresif. Dalam hal ini perusahaan keluarga lebih rela dalam pembayaran hutang pajaknya, daripada harus membayar denda pajak akibat melakukan tindakan pajak agresif dan adanya kemungkinan nilai perusahaan tersebut turun yang diakibatkan kegiatan audit dari petugas perpajakan.

Hasil pengujian statistik yang berikutnya memberikan hasil bahwa likuiditas berpengaruh positif signifikan terhadap agresivitas pajak, maka H2 yaitu likuiditas berpengaruh negatif terhadap agresivitas pajak ditolak. Hasil penelitian ini sejalan dengan penelitian sebelumnya yang dilakukan oleh Adisamartha dan Noviari (2015) serta Ardy dan Kristanto (2015). Penelitian ini menunjukkan bahwa semakin tinggi tingkat likuiditas suatu perusahaan maka semakin tinggi pula perusahaan melakukan tindakan agresif terhadap pajak dan begitupun sebaliknya. Dalam teori akuntansi positif menjelaskan bagaimana perusahaan melakukan manajemen laba dengan mengalokasikan laba periode berjalan ke periode selanjutnya (Yogiswari \& Ramantha, 2017). Hasil ini mengkonfirmasi adanya keterkaitan antara likuiditas dengan profitabilitas, apabila perusahaan dalam kondisi profitabilitas yang tinggi maka akan mempengaruhi nilai likuiditas yang juga akan naik. Sehingga perusahaan dengan tingkat likuiditas yang tinggi akan berusaha untuk mengalokasikan laba periode berjalan ke periode mendatang dan akan lebih agresif terhadap pajak, sehingga beban pajak yang dibayarkan akan berkurang. 
Berdasarkan hasil pengujian variabel moderating dapat disimpulkan bahwa komisaris independen dapat memperlemah pengaruh kepemilikan keluarga pada agresivitas pajak namun komite audit tidak dapat memoderasi pengaruh kepemilikan keluarga pada agresivitas pajak. Maka H3a yaitu komisaris independen dapat memoderasi pengaruh kepemilikan keluarga pada agresivitas pajak diterima dan H3b yaitu komite audit dapat memoderasi pengaruh kepemilikan keluarga pada agresivitas pajak ditolak. Hasil penelitian ini tidak sejalan dengan penelitian sebelumnya yang dilakukan oleh Utami dan Setyawan, (2015) namun sejalan dengan penelitian (Fahriani, 2016). Kepemilikan saham mayoritas yaitu dari kalangan keluarga tentu memiliki hak suara lebih besar sehingga pemilik dapat menentukan arah kebijakan bagi perusahaan. Manajemen perusahaan dapat dipengaruhi oleh pemegang saham mayoritas yang bertindak sesuai keinginan pemilik, tidak menutup kemungkinan untuk mengurangi beban pajak dan melakukan tindakan agresif terhadap pajak.

Penelitian ini memberikan fakta empirik bahwa keberadaan komisaris independen dapat memperlemah perusahaan keluarga dalam bertindak agresif terhadap pajak. Dapat disimpulkan bahwa komisaris independen dengan prinsip independensinya dalam suatu struktur perusahaan akan menjalankan fungsi pengawasan dengan optimal untuk melihat bagaimana perusahaan menghasilkan laba dan tidak dapat dipengaruhi oleh pihak-pihak dalam perusahaan untuk berlaku tidak independen. Sehingga praktik-praktik kecurangan seperti tindakan agresivitas pajak dapat teratasi. Hasil yang selanjutnya memberikan bukti bahwa keberadaan komite audit tidak dapat memperlemah atau memperkuat perusahaan keluarga dalam bertindak agresif terhadap pajak. Penjelasan atas hal ini mempunyai kemungkinan bahwa penerapan corporate governance yang ada di Indonesia masih relatif rendah. Tujuan penerapan good corporate governance bagi perusahaan publik cenderung untuk memenuhi tuntutan regulasi semata.

Hasil pengujian variabel moderating yang selanjutnya dapat disimpulkan bahwa komisaris independen dan komite audit dapat memperlemah pengaruh likuiditas pada agresivitas pajak. Maka $\mathrm{H} 4 \mathrm{a}$ yang menyatakan bahwa komisaris independen dapat memoderasi pengaruh likuiditas pada agresivitas pajak diterima. Demikian juga dengan $\mathrm{H} 4 \mathrm{~b}$ yang menyebutkan bahwa komite audit dapat memoderasi pengaruh likuiditas pada agresivitas pajak diterima. Hasil penelitian ini tidak sejalan dengan penelitian sebelumnya yang dilakukan oleh Yogiswari dan Ramantha (2017) serta Fahriani (2016). Manajemen seringkali bersifat opportunistic, mereka memiliki motivasi memaksimalkan laba agar meningkatkan insentif dengan cara menekan biayabiaya termasuk pajak, sehingga mendorong perilaku agresif terhadap pajak 
(Nuryaman, 2009). Dalam penelitian ini memberikan bukti bahwa keberadaan komisaris independen dan komite audit dalam perusahaan dapat menekan dan memperlemah perilaku manajemen laba (earnings management). Dapat disimpulkan bahwa keberadaan komisaris independen yang dinilai mempunyai pengawasan lebih baik, dapat mendorong manajemen perusahaan agar dalam menghasilkan laba sesuai aturan yang berlaku salah satunya taat akan peraturan perpajakan. Kemudian keberadaan komite audit dalam membantu komisaris yang bertanggung jawab atas pengawasan laporan keuangan, pengawasan pengendalian internal, dan pengawasan audit internal akan memperkecil ruang lingkup atas tindakan manajemen laba. Monitoring secara berkelanjutan akan meminimalisir tindakan agresif terhadap pajak dan hal-hal yang merugikan perusahaan.

\section{Simpulan}

\section{Kesimpulan}

Penelitian ini menguji pengaruh kepemilikan keluarga dan likuiditas terhadap agresivitas pajak dengan corporate governance sebagai variabel moderasi yang terdaftar di Bursa Efek Indonesia pada tahun 2013-2016. Hasil analisis dan pembahasan sebelumnya dapat disimpulkan bahwa kepemilikan keluarga tidak berpengaruh terhadap agresivitas pajak. Hal ini berarti perusahaan dengan kepemilikan keluarga tidak menentukan tindakan perusahaan dalam melakukan agresivitas pajak. Kedua, likuiditas berpengaruh positif signifikan terhadap agresivitas pajak. Ketiga, keberadaan komisaris independen dapat memoderasi (memperlemah) pengaruh kepemilikan keluarga terhadap agresivitas pajak. Keempat, keberadaan komite audit tidak dapat memoderasi pengaruh kepemilikan keluarga terhadap agresivitas pajak. Kelima, keberadaan komisaris independen dapat memoderasi (memperlemah) pengaruh likuiditas terhadap agresivitas pajak. Keenam, keberadaan komite audit dapat memoderasi (memperlemah) pengaruh likuiditas terhadap agresivitas pajak.

\section{Keterbatasan Penelitian dan Saran}

Penelitian ini masih memiliki kekurangan dan keterbatasan, sehingga penelitian ini dapat menjadi rujukan agar lebih baik untuk penelitian mendatang. Besar pengaruh variabel bebas terhadap variabel terikat yang relatif rendah yaitu menunjukkan nilai R Squre sebesar 24,7\%. Dalam penelitian ini hanya mengambil sampel dari perusahaan manufaktur dan hanya menggunakan 4 (empat) tahun pengamatan, sehingga hasil penelitian ini belum menggambarkan secara keseluruhan mengenai tindakan pajak agresif. Terdapat beberapa sub sektor yang tidak terwakili yaitu diantaranya 
sub sektor kayu dan pengolahannya, mesin dan alat berat, elektronika, dan yang terakhir peralatan rumah tangga.

Saran yang dapat penulis ajukan terkait dengan penelitian ini bagi peneliti lain adalah sebagai berikut: (1) menambah periode penelitian dan memperluas obyek penelitian pada sektor-sektor perusahaan yang lain, sehingga hasil penelitian lebih menggambarkan hasil yang sesuai. (2) menggunakan ukuran lain seperti Book Tax Differences (BTD), discretionary accrual, dan ukuran lainnya untuk memproksikan agresivitas pajak. (3) menambahkan variabelvariabel lain yang diduga mampu memberikan pengaruh yang lebih baik terhadap tindakan pajak agresif.

\section{Daftar Pustaka}

Adisamartha, I. B., \& Noviari, N. (2015). Pengaruh Likuiditas, Leverage, Intensitas Persediaan dan Intensitas Aset Tetap pada Tingkat Agresivitas Wajib Pajak Badan. E-Jurnal Akuntansi Universitas Udayana, 13.3, 973-1000.

Andriyani, N. (2008). Pengaruh Investment Opportunity Set (IOS), Mekanisme Corporate governance, Ukuran Perusahaan dan Leverage pada Kualitas Laba. Skripsi, Fakultas Ekonomi Universitas Udayana. Denpasar.

Ardy, \& Kristanto, A. B. (2015). Faktor Finansial dan Non Finansial yang Mempengaruhi Agresivitas Pajak di Indonesia. Media Riset Akuntansi, Auditing \& Informasi, 15(1).

Chen , S., Chen , X., Cheng, Q., \& Shevlin, T. (2010). Are Family Firms More Tax Aggressive Then Non-Family Firms ? Journal of Financial Economics, 95, 4161.

Darmadi , I. N. (2013). Analisis Faktor yang Mempengaruhi Manajemen Pajak dengan Indikator Tarif Pajak Efektif. Skripsi, Fakultas Ekonomi Universitas Diponegoro. Semarang.

Darmawan, G. H., \& Sukartha, M. (2014). Pengaruh Penerapan Corporate governance, Leverage, ROA, dan Ukuran Perusahaan pada Penghindaran Pajak. E-Jurnal Akuntansi Universitas Udayana, 9(1), 143-161.

Desai, M., \& Dharmapala, D. (2004). Corporate Tax avoidance and High Powered Incentives. Journal of Financial Economics, 79(1), 145-179.

Fahriani, M. (2016). Pengaruh Good Corporate governance Terhadap Tindakan Pajak Agresif Pada Perusahaan Manufaktur. Jurnal Ilmu dan Riset Akuntansi, 5(7).

Fitria, M. (2015). Pengaruh Struktur Kepemilikan, Ukuran Perusahaan dan Kualitas Audit terhadap Manajemen Laba. Jurnal Ilmu \& Riset Akuntansi, 4(6).

Frank, M. M., Lynch, L., \& Rego, S. (2009). Tax Reporting Aggressiveness and its Relation to Aggressive Financial Reporting. Accounting Review, 84(2).

Ghozali, I. (2013). Aplikasi Analisis Multivariate dengan Program IBM SPSS 23 Update PLS Regresi. Semarang: Badan Penerbit Universitas Diponegoro.

Hanum, H. R., \& Zulaikha. (2013). Pengaruh Karakteristik Corporate governance terhadap Effective Tax Rate (Studi Empiris pada BUMN yang Terdaftar di BEI 2009-2011). 2(2), 1-10. 
Hidayanti, A. N., \& Laksito, H. (2013). Pengaruh antara Kepemilikan Keluarga dan Corporate governance terhadap Tindakan Pajak Agresif. Diponegoro Journal of Accounting, 2(2), 1-12.

Kurniasih , T., \& Sari, M. R. (2013). Pengaruh Return on Assets, Leverage, Corporate governance, Ukuran Perusahaan, dan Kompensasi Rugi Fiskal pada Tax Avoidance. Buletin Studi Ekonomi, 18(1), 58-66.

Lanis, R., \& Richardson, G. (2012). Corporate Social Responsibility and Tax Aggressiveness : a test of legitimacy theory. Accounting, Auditing \& Accountability Journal, 26(1), 75-100.

Liana, L. (2009). Penggunaan MRA dengan SPSS untuk Menguji Pengaruh Variabel Moderating terhadap Hubungan antara Variabel Independen dan Variabel Dependen. Jurnal Teknologi Informasi DINAMIK, 14, 90-97.

Luke, \& Zulaikha. (2016). Analisis Faktor yang Mempengaruhi Agresivitas Pajak. Diponegoro Journal of Accounting, 13(1), 80-96.

Morck, R., \& Yeung, B. (2004). Special Issues Relating to Corporate governance and Family Control. World Bank Policy Research Working Paper.

Nuryaman. (2009). Pengaruh Konsentrasi Kepemilikan, Ukuran Perusahaan, dan Mekanisme Corporate governance terhadap Pengungkapan Sukarela. Jurnal Akuntansi dan Keuangan (JAKI), 89-116.

Pohan, H. T. (2011). Pengaruh Good Corporate governance, Rasio Tobin Q, Perata Laba Terhadap Penghindaran Pajak pada Perusahaan Publik. Skripsi, Fakultas Ekonomi Universitas Trisakti. Jakarta.

Praptidewi , L. P., \& Sukartha, M. (2016). Pengaruh Karakter Eksekutif dan Kepemilikan Keluarga pada Tax avoidance Perusahaan. E-Jurnal Akuntansi Universitas Udayana, 17(1), 426-452.

Rudsyi, K., \& Martani, D. (2014). Pengaruh Struktur Kepemilikan terhadap Aggressive Tax Avoidance. Simposium Nasional Akuntansi XVII.

Sari, D. K., \& Martani, D. (2010). Karakteristik Kepemilikan Perusahaan, Corporate governance, dan Tindakan Pajak Agresif. Simposium Nasional Akuntansi, 13.

Siahaan, F. O. (2005). Faktor-Faktor yang Mempengaruhi Perilaku Kepatuhan Tax Professional dalam Pelaporan Pajak Badan pada Perusahaan Industri Manufaktur di Surabaya. Thesis, Program Pasca Sarjana Universitas Airlangga. Surabaya.

Sirait, N. S., \& Martani, D. (2014). Pengaruh Perusahaan Keluarga terhadap Penghindaran Pajak pada Perusahaan Manufaktur di Indonesia dan Malaysia. Simposium Nasional Akuntansi XVII.

Suyanto, K. D., \& Supramono. (2012). Likuiditas, Leverage, Komisaris Independen, dan Manajemen Laba terhadap Agresivitas Pajak Perusahaan. Jurnal Keuangan dan Perbankan, 16(2), 167-177.

Utami, W. T., \& Setyawan, H. (2015). Pengaruh Kepemilikan Keluarga terhadap Tindakan Pajak Agresif dengan Corporate governance sebagai Variabel Moderating. Conference in Business, Accounting, and Management, 2(1).

Wirawan, I. G., \& Sukartha, I. M. (2018). Pengaruh Kepemilikan Keluarga dan Ukuran Perusahaan pada Agresivitas Pajak dengan Corporate governance sebagai Variabel Pemoderasi. E-Jurnal Akuntansi Universitas Udayana, 23.1, 595-625. 
Yogiswari, N. K., \& Ramantha, W. (2017). Pengaruh Likuiditas dan Corporate Cocial Responsibility pada Agresivitas Pajak dengan Corporate governance sebagai Variabel Pemoderasi. E-Jurnal Akuntansi Universitas Udayana, 21(1), 730759. 